\title{
Genotyping of group A rotavirus samples from Brazilian children by probe hybridization
}

\author{
D.D.P. Cardoso ${ }^{1}$, \\ M.L. Rácz ${ }^{3}$, \\ M.S.P. Azevedo ${ }^{1}$ \\ R.M.B. Martins ${ }^{1}$ \\ and C.M.A. Soares²
}

\author{
'Laboratório de Virologia, Instituto de Patologia Tropical e Saúde Pública, and \\ ${ }^{2}$ Laboratório de Biologia Molecular, Instituto de Ciências Biológicas, \\ Universidade Federal de Goiás, Goiânia, GO, Brasil \\ ${ }^{3}$ Laboratório de Virologia, Instituto de Ciências Biológicas, \\ Universidade de São Paulo, São Paulo, SP, Brasil
}

\section{Correspondence \\ D.D.P. Cardoso \\ IPTSP/UFG \\ Rua Delenda Rezende M elo \\ Esquina com $1 \stackrel{\text { a Avenida }}{ }$ \\ Setor Universitário \\ 74605-050 Goiânia, GO \\ Brasil \\ Fax: + 55-62-202-3066 \\ E-mail: divina@ netgo.com.br \\ Research supported by CN Pq ( $\mathrm{No}$. 800149-89/0) and Fundação de Apoio à Pesquisa-FU NAPE/PRPPG/ UFG. Publication supported by FAPESP.}

Received July 25, 2000

Accepted February 5, 2001

\section{Abstract}

The G genotyping of 74 group A rotavirus samples was done by RNADNA hybridization (dot-blot) using oligonucleotide probes for the VP7 gene region of the human rotavirus serotypes/genotypes 1, 2, 3 and 4 . Thirty-one samples could be genotyped by dot-blot showing the following results: $\mathrm{G} 1=16, \mathrm{G} 4=6, \mathrm{G} 3=5$, and $\mathrm{G} 2=4$. The data show circulation of genotypes G1-G4 and the predominance of G1. The knowledge of genotypes provides important information concerning rotavirus circulation in Central Brazil.

Human rotaviruses are recognized as the main agents of diarrhea of infants and young children and constitute an important cause of mortality in developing countries. The knowledge of the relative frequency and distribution of rotavirus serotypes/genotypes can help in the analysis of regional differences and variations over the years in population samples (1). The G serotypes/genotypes can be analyzed by several techniques (2-6), including enzyme immunoassay with monoclonal antibodies (EIA-mAb) $(7,8)$. This is the main technique, although it is not able to define all serotypes. It has been proposed that the failure in serotyping by EIA-mAb could be due, for example, to the loss of VP7 $(7,9)$. Nucleic acid hybridization techniques can be used to determine genotypes since the viral doublestranded RNA (dsRNA) is more resistant to degradation than the VP7 protein (10).

The present study describes the data obtained from $\mathrm{G}$ genotyping of rotavirus samples collected from children in Goiânia, GO, Brazil, using the RNA-DNA hybridization technique. We studied 2,158 samples from children up to 10 years of age, with or without diarrhea disease, collected from hospitals, outpatient clinics and day-care centers from March 1986 to June 1995. All fecal samples were previously tested by EIA for group A rotavirus using commercial kits (EIARA, Biomanguinhos, FIOCRUZ, Rio de Janeiro, RJ, Brazil) and RNA polyacrylamide gel electrophoresis (PAGE) $(11,12)$. Two hundred and fifty-four samples were positive for group A rotavirus. Of the 254 rotavirus samples, 233 (91.7\%) were from children with diarrhea. It should be pointed out that $226(95.8 \%)$ were hospitalized children. In addition, regarding age, 220 of the 254 positive children were up to two years old. Seventy-four of the positive samples were genotyped by the hybridization technique (dot-blot). Probes complementary to nucleo- 
tides 315-339 of the VP7 gene from the human rotavirus serotypes/genotypes 1,2,3, and 4 were synthesized as described by Sethabutr et al. (10). The primers were labeled with $\left[\gamma^{32} \mathrm{P}\right]-\mathrm{ATP}$ according to Sambrook et al. (13). dsRNA was extracted from the samples as described by Pereira et al. (11). Briefly, fecal samples were suspended in 1X PBS, pH $7.4(0.14 \mathrm{M} \mathrm{NaCl}$, $0.02 \mathrm{M} \mathrm{KCl}, 0.08 \mathrm{M} \mathrm{Na}_{2} \mathrm{HPO}_{4}, 0.01 \mathrm{M}$ $\mathrm{KH}_{2} \mathrm{PO}_{4}$ ), extracted with phenol-chloroform and precipitated with ethanol. Hybridization was performed by the method of Sethabutr et al. (10). Briefly, dsRNA was supplemented with the same volume of 20X SSC (20X SSC $=3 \mathrm{M} \mathrm{NaCl}$ plus $0.3 \mathrm{M}$ sodium citrate) $/ 37 \%$ formaldehyde ( 3 parts of SSC and 2 parts of formaldehyde) and heated at $65^{\circ} \mathrm{C}$ for 15 min. The denatured dsRNA was spotted on nitrocellulose membranes in a total volume of $25 \mu 1$. The membranes were heated for $2 \mathrm{~h}$ at $80^{\circ} \mathrm{C}$ and pre-hybridized in a solution containing $50 \%$ formamide, $1 \mathrm{mg} / \mu \mathrm{l}$ salmon DNA, 50\% Denhardt's solution (Ficoll/polyvinylpyrrolidone/bovine serum albumin), and $1 \mathrm{M}$ sodium phosphate buffer. The pre-hybridization and hybridization temperatures were $38^{\circ} \mathrm{C}$ for genotypes with 2 and 3 oligonucleotides and $42^{\circ} \mathrm{C}$ for genotypes with 1 and 4 oligonucleotides. Pre-hybridization was carried out for $4 \mathrm{~h}$, followed by hybridization for $18 \mathrm{~h}$ in the same solution with $0.1 \%$ SDS and the labeled oligonucleotide added. The membranes were washed three times with

Table 1 - Distribution of rotavirus G genotypes detected by probe hybridization in the State of Goiás.

\begin{tabular}{lrr}
\hline Genotype & No. & \multicolumn{1}{c}{$\%$} \\
\hline G1 & 16 & 21.6 \\
G2 & 4 & 5.4 \\
G3 & 5 & 6.8 \\
G4 & 6 & 8.1 \\
Reactive to more than one probe & 9 & 12.1 \\
Not genotyped & 34 & 45.9 \\
Total & 74 & 100.0
\end{tabular}

solution containing $5 \mathrm{X} \mathrm{SSC}$ and $0.1 \%$ SDS at room temperature, dried and exposed to an X-ray film for $24 \mathrm{~h}$ at $-70^{\circ} \mathrm{C}$.

Genotyping was considered positive when the signal for one genotype was unique or significantly higher than for the other genotypes (at least two times the intensity). Samples that presented the same signal intensity for more than one genotype were considered undetermined. The prototypes $\mathrm{Wa}$ (G1), SA-11 (G3) and ST-3 (G4) were used as positive controls. We also used one sample (9800) characterized by EIA-mAb as a positive control of genotype G2.

Table 1 shows the results of genotyping. Of 74 samples analyzed, 31 (41.9\%) were assigned to genotypes G1 to G4 by dot-blot. Indices from 52.9 to $91.1 \%$ were described for genotyping using molecular techniques $(10,14,15)$. Thirty-four samples $(45.9 \%)$ were not genotyped by dot-blot analysis. The presence of dsRNA was observed by PAGE in 33 of 34 dot-blot-negative samples (data not shown), a fact excluding the possibility of the failure of genotyping being related to the absence of dsRNA, as suggested by Bingnan et al. (1). Negative results could be related to the failure of hybridization with the oligonucleotides due to the presence of other VP7 genes not included in this investigation, as well as mutation in the analyzed region $(14,16,17)$. Bingnan et al. (1), in Bangladesh, observed a higher genotyping index (66.7\%) using three additional oligonucleotides for other rotavirus genotypes. This result supports the suggestion of the occurrence of samples other than G1-G4 among the samples analyzed. In agreement, other serotypes have been described. The G5 serotype that infects mainly swine has been detected in Brazil $(18,19)$. Oligonucleotides complementary to other VP7 regions, as well as oligonucleotides for other rotavirus serotypes should be useful to answer this question. Nine samples hybridized with more than one oligonucleotide probe. The significance of this result will be the subject of a future study. Our data 
support the need for continuous monitoring of rotavirus serotypes/genotypes at different times in different world regions.

\section{Acknowledgments}

The authors would like to thank Adriana Crispim Azevedo for helpful technical assistance.

\section{References}

1. Bingnan $F$, Unicomb L, Rahi Z, Banu NN, Podder G, Clemens J , Van Lonn FPL, Rao MR, Malek A \& Tzipori S (1991). Rotavirusassociated diarrhea in rural Bangladesh: Two-year study of incidence and serotype distribution. J ournal of Clinical Microbiology, 29: 1359-1363.

2. Gerna G, Passarani N, Battaglia $M$ \& Percivalle E (1984). Rapid serotyping of human rotavirus strains by solid-phase immune electron microscopy. J ournal of Clinical Microbiology, 19: 273-278.

3. Green KY, Sears J F, Taniguchi K, Midthun K, Hoshino Y, Gorziglia M, Nishikawa K, Urasawa S, Kapikian AZ, Chanock RM \& Flores J (1988). Prediction of human rotavirus serotype by nucleotide sequence analysis of the VP7 protein gene. J ournal of Virology, 62: 1819-1823.

4. Greenberg HB, Wyatt RG, Kapikian AZ, Kalica AR, Flores J \& J ones R (1982). Rescue and serotypic characterization of noncultivable human rotavirus by gene reassortment. Infection and Immunity, 37: 104-109.

5. Lin $M$, Imai $M$, Ikegami $N$, Bellamy $A R$, Summers D, Nuss DL, Deibel R \& Furuichi $Y$ (1987). CDNA probes of individual genes of human rotavirus distinguish viral subgroups and serotypes. J ournal of Virological Methods, 15: 285-289.

6. Poncet D \& Cohen J (1989). A plaque hybridization assay for rotaviruses. J ournal of Virological Methods, 26: 27-33.

7. Thouless ME, Beards GM \& Flewett TH (1982). Serotyping and subgrouping of rotavirus strains by the ELISA test. Ar- chives of Virology, 73: 219-230.

8. Gusmão RH, Mascarenhas J D, Gabbay YB, Lins Lainson Z, Ramos FL, Monteiro TA, Valente AS, Fagundes Neto $U$ \& Linhares AC (1999). Rotavirus subgroups, $G$ serotypes, and electrophoretypes in cases of nosocomial infantile diarrhoea in Belém, Brazil. J ournal of Tropical Pediatrics, 45: 81-86.

9. Mohammed KA, El Assouli SM \& Banjar ZM (1994). Human rotavirus subgroups and serotypes in children with acute gastroenteritis in Saudi Arabia from 1988 to 1992. J ournal of Medical Virology, 44: 237-242.

10. Sethabutr $\mathrm{O}$, Unicomb LE, Holmes $\mathrm{IH}$, Taylor DN, Bishop RF \& Echeverria P (1990). Serotyping of human group A rotavirus with oligonucleotide probes. J ournal of Infectious Diseases, 162: 368372.

11. Pereira HG, Azeredo RS, Leite J PG, Barth OM, Sutmoller F, Farias V \& Vidal MNP (1983). Comparison of polyacrylamide gel electrophoresis (PAGE), immunoelectron microscopy (IEM) and enzyme immunoassay (EIA) for the rapid diagnosis of rotavirus infection in children. Memórias do Instituto Oswaldo Cruz, 78: 483-490.

12. Pereira HG, Azeredo RS, Leite JPG, Andrade ZP \& De Castro L (1985). A combined enzyme immunoassay for rotavirus and adenovirus (EIARA). J ournal of Virological Methods, 10: 21-28.

13. Sambrook J, Fritsch EF \& Maniatis $T$ (1989). Molecular Cloning: A Laboratory Manual. 2nd edn. Cold Spring Harbor,
New York, 11.31-11.32.

14. Nirdnoy W, Sethabutr O, Sakulkaipeara T, Harikul S, Hoge CW \& Echeverria $P$ (1995). Typing of human group A rotavirus with alkaline phosphatase-labeled oligonucleotide probes or a monoclonal enzyme immunoassay in unfrozen stools of children with diarrhea in Bangkok. J ournal of Medical Virology, 45: 117-120.

15. Adah MI, Rohwedder A, Olaleye OD, Durojalye OA \& Werchau H (1997). Serotype of Nigerian rotavirus strains. Tropical Medicine and International Health, 2: 363370.

16. Steele AD, Nierkerk MC \& M phahlele MJ (1995). Geographic distribution of human rotavirus VP4 genotypes and VP7 serotypes in five South African geographic regions. J ournal of Clinical Microbiology, 33: 1516-1519.

17. Adah MI, Rohwedder A, Olaleyle OD \& Werchau H (1997). Nigerian rotavirus serotype $\mathrm{G} 8$ could not be typed by PCR due to nucleotide mutation at the 3 'end of the primer binding site. Archives of Virology, 142: 1881-1887.

18. Gouvea V, Castro L, Timenetsky MC, Greenberg H \& Santos N (1994). Rotavirus serotype G5 associated with diarrhea in Brazilian children. J ournal of Clinical Microbiology, 32: 1408-1409.

19. Leite J PG, Alfieri AA, Woods PA, Glass RI \& Gentsch J R (1996). Rotavirus $G$ and $P$ types circulating in Brazil: characterization by RT-PCR, probe hybridization, and sequence analysis. Archives of Virology, 141: 2365-2374. 